\title{
Dynamic Characteristics of Saturated Silty Soil Ground Treated by Stone Column Composite Foundation
}

\author{
Yongxiang Zhan, ${ }^{1,2}$ Guanlu Jiang, ${ }^{3}$ and Hailin Yao ${ }^{1,2}$ \\ ${ }^{1}$ Institute of Rock and Soil Mechanics, Chinese Academy of Sciences, Wuhan 430071, China \\ ${ }^{2}$ State Key Laboratory of Geomechanics and Geotechnical Engineering, Institute of Rock and Soil Mechanics, \\ Chinese Academy of Sciences, Wuhan 430071, China \\ ${ }^{3}$ School of Civil Engineering, Southwest Jiaotong University, Chengdu 610031, China
}

Correspondence should be addressed to Yongxiang Zhan; zhanyongxiang@126.com

Received 10 January 2014; Accepted 22 April 2014; Published 19 May 2014

Academic Editor: Mohd Sapuan Salit

Copyright (C) 2014 Yongxiang Zhan et al. This is an open access article distributed under the Creative Commons Attribution License, which permits unrestricted use, distribution, and reproduction in any medium, provided the original work is properly cited.

A shaking table model test was carried out to develop an understanding of the performance improvement of saturated silty soil ground using stone column composite foundation as reinforcement. It is found that at less than $0.161 \mathrm{~g}$ loading acceleration, soil between piles has not yet been liquefied, the response acceleration scarcely enlarges, and the shear displacement almost does not appear in silty soil. At $0.252 \mathrm{~g}$ loading acceleration, as a result of liquefaction of soil between piles, the response acceleration increases rapidly and reaches its peak, and the shear displacement of silty soil increases significantly. At $0.325 \mathrm{~g}$ loading acceleration, the integral rigidity of foundation decreases greatly, which reduces its capability of vibration transmission and result in the response acceleration amplification coefficient is less than that at the former loading acceleration, but the shear displacement of silty soil further increases. The stone column composite foundation can greatly reduce both the shear displacement and the settlement of ground compared with untreated foundation. Under the condition of 7-degree seismic fortification, the design meets seismic resistance requirements.

\section{Introduction}

Beijing-Shanghai high speed railway is the first line of over $300 \mathrm{~km} / \mathrm{h}$ in China, which is built on large acreage of silty soil ground that is mainly located in Haihe river basin, alluvial, and deposit zone of Yellow River, Yellow River old channel, Yangtze River deposit zone, and alluvial and deposit zone of other rivers. These areas belong to earthquake zones of 7,8 , and 9 seismic intensities, and the saturated silty soil ground is of high liquefaction potential under seismic load.

Construction of embankments on silty soil is a very challenging task due to possible bearing failure, excessive settlement, and local and global instability under dynamic load [1]. Stone column composite foundation (as shown in Figure 1), one of the most commonly used soil improvement technique, has been utilized worldwide to increase the bearing capacity of soft soils and reduce the settlement of superstructures constructed on them. Several researches have been carried out to study the behaviour of stone column-reinforced ground in recent years [2-12]. In these studies, stone columns are typically used in soft soils, as these cannot be compacted. Being highly permeable the stone columns act as vertical drains facilitating consolidation of the soft clay around and thereby improving the long term performance of the foundation system. But few searches conducted for the study focused on the stone column methods with respect to the effectiveness in keeping permanent seismic deformation to sufficiently low levels in sandy and silty soils. Horizontal geosynthetic reinforcement sheets can be used in the granular columns to increase the load-carrying capacity as well as decrease the bulging of the columns [13-16]. A granular layer of sand or gravel, $0.3 \mathrm{~m}$ or more in thickness, is usually placed over the top of the stone columns to provide a drainage path 
TABle 1: Physical and mechanical parameters of the in situ soil.

\begin{tabular}{|c|c|c|c|c|c|c|c|}
\hline Soil type & $\begin{array}{l}\text { Natural water } \\
\text { content } / \%\end{array}$ & $\begin{array}{c}\text { Natural bulk } \\
\text { density } / \mathrm{kN} \cdot \mathrm{m}^{-3}\end{array}$ & Relative density & $\begin{array}{c}\text { Natural } \\
\text { porosity ratio }\end{array}$ & $\begin{array}{c}\text { Cohesive } \\
\text { strength } / \mathrm{kPa}\end{array}$ & $\begin{array}{l}\text { Internal } \\
\text { friction } \\
\text { angle/。 }\end{array}$ & $\begin{array}{c}\text { Clay } \\
\text { particle } \\
\text { content } / \%\end{array}$ \\
\hline Silty & 30.4 & 19.1 & 2.7 & 0.9 & 7.0 & 34.8 & 6.9 \\
\hline Clay & 27.2 & 19.8 & 2.7 & 0.8 & 27 & 14 & - \\
\hline
\end{tabular}

TABLE 2: Specific technical characteristic parameters of shaking table.

\begin{tabular}{lcccccc}
\hline $\begin{array}{l}\text { Size of } \\
\text { shaking table } \\
\text { board } / \mathrm{m}^{2}\end{array}$ & $\begin{array}{c}\text { Range of } \\
\text { frequency/Hz }\end{array}$ & $\begin{array}{c}\text { Maximum } \\
\text { payload } \\
\text { capacity/T }\end{array}$ & $\begin{array}{c}\text { Maximum } \\
\text { displacement } / \mathrm{mm}\end{array}$ & $\begin{array}{c}\text { Maximum } \\
\text { acceleration/g }\end{array}$ & Wave form & Driving way \\
$5 \times 5$ & $0.1-120$ & 20 & $\begin{array}{c}\text { Horizontal } \pm 40 \\
\text { Vertical } \pm 30\end{array}$ & $\begin{array}{c}\text { Horizontal } 1.0 \\
\text { Vertical } 0.7\end{array}$ & $\begin{array}{c}\text { Regular wave } \\
\text { Seismic wave }\end{array}$ & Electrohydraulic servo \\
\hline
\end{tabular}

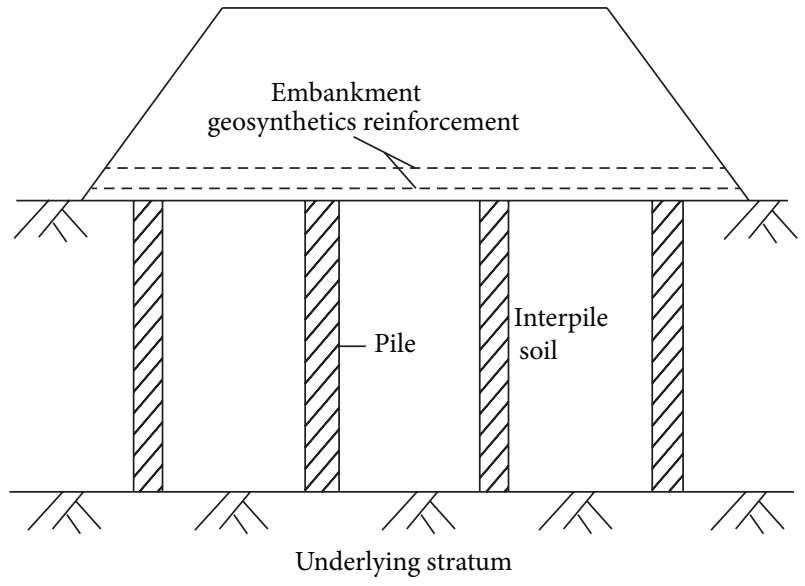

FIGURE 1: Diagram of stone column composite foundation.

and distribute the stresses coming from the superstructures [17].

It has been observed that many analytical or numerical studies have been carried out to study the effect of unreinforced and geogrid-reinforced granular bed on settlement and bearing capacity of stone column-improved soft soil. Very limited experimental investigations have been conducted on this topic, especially for liquefied soil foundation reinforced with stone column composite foundation.

In recent years, different forms of filling soil devices, such as rigid sand box [18], cylinder type flexible sand box, and laminar shear box [19], are used for shaking table test to research soil liquefaction and the interaction of pilesoil-structure. Relative to the rigid and flexible filling soil devices, the laminar shear box is better at simulating shear deformation and lateral restraint. In this paper, a shaking table model test is carried out using a large-scale laminar shear box to study the dynamic characteristics of saturated silty soil ground reinforced by stone column composite foundation under seismic load.

\section{Engineering Background}

The ground of line between DK719 + 525 and DK720 + 057 is typical saturated silty soil of Beijing-Shanghai high speed railway, which is liquefied soil under 7-degree seismic fortification. So the line is considered to be the prototype of shaking table model test. Along the line, the average height of silty soil layer is about $8 \mathrm{~m}$, and the subjacent bed is stiff-plastic clay layer. Stone column composite foundation is used to improve the liquefied soil ground, and its design parameters are as follows: pile diameter is $0.5 \mathrm{~m}$, pile spacing is $1.2 \mathrm{~m}$, pile length is $9.5 \mathrm{~m}$, and pile depth penetrating into stiff-plastic clay layer is $1.5 \mathrm{~m}$. Height of gravel cushion is $0.6 \mathrm{~m}$, middle of which lays a layer of geogrid with tensile strength no less than $50 \mathrm{kN} / \mathrm{m}$. Table 1 shows physical and mechanical parameters of the in situ soil.

\section{Design and Construction of the Model}

3.1. Design of Model Box. A large-scale laminar shear box with inner size of $4.0 \mathrm{~m} \times 1.5 \mathrm{~m} \times 2.5 \mathrm{~m}$ is designed, as shown in Figure 2, which is stacked with 23 layers of independent rectangular frameworks and can effectively reduce the boundary effect of both ends in the shaking direction. Ball-bearings are set up between the rectangular framework to ensure each layer slide freely in the level direction, and two groups of constraint frameworks are set up at side of the box to limit its lateral movement and turn. The bottom framework is fixed in the shaking table board, and a layer of $1.5 \mathrm{~mm}$ thickness of rubber bag is set inside the box to prevent seepage. Table 2 shows the specific technical characteristic parameters of shaking table.

3.2. Design of Scale Model. Considering the limit of laminar shear box space and payload capacity of shaking table, geometrical proportion of $1: 10$ is first fixed. Since gravitational acceleration simulation must be considered in shaking table test, similarity coefficient of mass density fixed for the test 


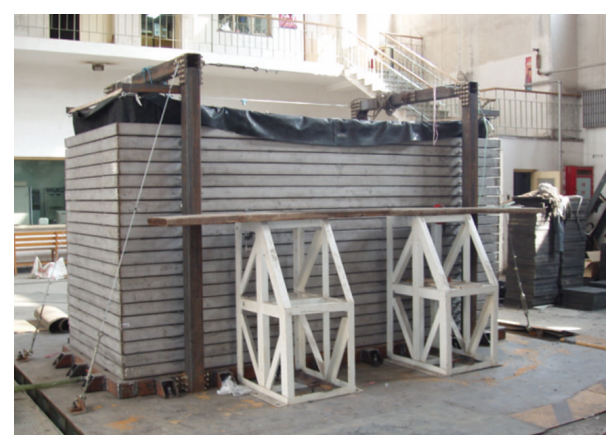

Figure 2: Design of large-scale laminar shear box.

TABLE 3: Similitude coefficients of the shaking table model test.

\begin{tabular}{lc}
\hline Physical quantity & Similarity coefficient \\
\hline Geometry $L$ & $C_{L}=0.1$ \\
Mass density $\rho$ & $C_{\rho}=1.0$ \\
Dynamic elastic modulus $E_{d}$ & $C_{E_{d}}=1$ \\
Dynamic Poisson ratio $\mu$ & $C_{\mu}=1$ \\
Frequency $\omega$ & $C_{\omega}=C_{L}{ }^{-1 / 2}=3.162$ \\
Damping coefficient $R$ & $C_{R}=1.0$ \\
Subgrade deadweight $P$ & $C_{P}=C_{L}{ }^{3}=0.001$ \\
Effective overlying stress $\sigma_{V}{ }^{\prime}$ & $C_{\sigma_{V}{ }^{\prime}}=C L=0.1$ \\
Gravitational acceleration $g$ & $C_{g}=1.0$ \\
Input acceleration $A$ & $C_{A}=1.0$ \\
Dynamic response stress $\sigma_{d}$ & $C_{\sigma_{d}}=C_{L}=0.1$ \\
Dynamic response angular & $C_{\theta}=1.0$ \\
displacement $\theta$ & \\
Dynamic response linear & $C_{S_{d}}=C_{L}=0.1$ \\
displacement $S_{d}$ & $C_{\varepsilon_{d}}=1.0$ \\
Dynamic response strain $\varepsilon_{d}$ & $C_{a}=1.0$ \\
Dynamic response acceleration $a$ & $C_{u}=C_{L}=0.1$ \\
Excess pore pressure $u$ &
\end{tabular}

is 1.0. Due to large reduction of boundary effect by using laminar shear box, similarity coefficients of damping and Poisson ratio are also fixed as 1.0. According to Bockingham $\pi$ theorem, other physical quantity similarity coefficients can be deduced by the dimensional analysis method [20], as shown in Table 3.

3.3. Design of Subgrade Model. Model foundation soil is acquired from the near prototype section, which dries in the air under the natural state. Before model subgrade filling, the water content of silty and clay is tested, which are converted into mass density of the filling soil. Model foundation is evenly compacted according to the standard of the weight of per $5 \mathrm{~cm}$ height to control its density and saturated 48 hours by discharging water from the model bottom after filling finished.

Model pile diameter is $50 \mathrm{~mm}$, model pile spacing is $120 \mathrm{~mm}$, and model pile length is $950 \mathrm{~mm}$, which means that the depth of model pile penetrating into stiff-plastic clay
TABLE 4: Input acceleration of the model test.

\begin{tabular}{lccccc}
\hline Loading frequency & \multicolumn{3}{c}{$1 \mathrm{~Hz}$} & \multicolumn{2}{c}{$2 \mathrm{~Hz}$} \\
\hline Loading order & 1 & 2 & 3 & 4 & 5 \\
Loading acceleration/g & 0.030 & 0.097 & 0.161 & 0.252 & 0.325 \\
\hline
\end{tabular}

layer is $150 \mathrm{~mm}$. The height of model net cushion is $60 \mathrm{~mm}$, which is filled with coarse sand. In the middle of the cushion, phosphor-bronze belt net is laid to simulate geogrid and its width and numbers of per $1 \mathrm{~m}$ width are fixed according to the tensile strength and deformation property of the geogrid, which are deduced from prototype in accordance with similarity coefficients.

Graded gravel, of which grain size is less than $20 \mathrm{~mm}$, is used for subgrade filling and compacted by layers. Phosphorbronze belt nets lay in the two sides of subgrade slope to simulate the reinforced geogrid. Cast iron shot evenly spreads on the subgrade surface to simulate the track dead load, which is derived from similarity coefficient. Figure 3 shows the model and arrangement of instruments.

\section{Test Loading Wave Pattern and Scheme}

Generally, natural frequency of foundation soil is 1 to $2 \mathrm{~Hz}$, so it takes $1 \mathrm{~Hz}$ as loading frequency in the test. Due to the limit of input acceleration of shaking table, loading frequency needs to increase appropriately under high loading acceleration, so it turns into $2 \mathrm{~Hz}$ when loading acceleration is more than $0.161 \mathrm{~g}$. In addition the maximum loading acceleration is higher than 7-degree seismic fortification value (peaking acceleration is $1.5 \mathrm{~g}$ ). The input wave form of the test is sine wave with load direction along the cross-section of embankment. It is loaded step by step from low to high, and the next step loading is carried on after the excess pore water pressure caused by the previous step loading is dissipated. The load time lasts 10 seconds and the collection time is 100 seconds. Table 4 shows the input loading acceleration.

\section{Test Results Analysis}

\subsection{Macrophenomena of the Test}

(1) At less than $0.161 \mathrm{~g}$ loading acceleration, there is no visible settlement on subgrade. While at $0.252 \mathrm{~g}$ loading acceleration, there is obvious uplift on both sides of ground surface, and the subgrade is damaged at $0.325 \mathrm{~g}$ loading acceleration.

(2) The horizontal shear displacement of ground is not obvious when loading acceleration is less and gradually increases with the increase of loading acceleration.

(3) At $0.252 \mathrm{~g}$ loading acceleration, sandboils and waterspouts begin to appear on ground surface. At $0.325 \mathrm{~g}$ loading acceleration, the water of ground surface further increases.

(4) Dredging the upper embankment after test finished, the deformation of ground surface is midst concave 


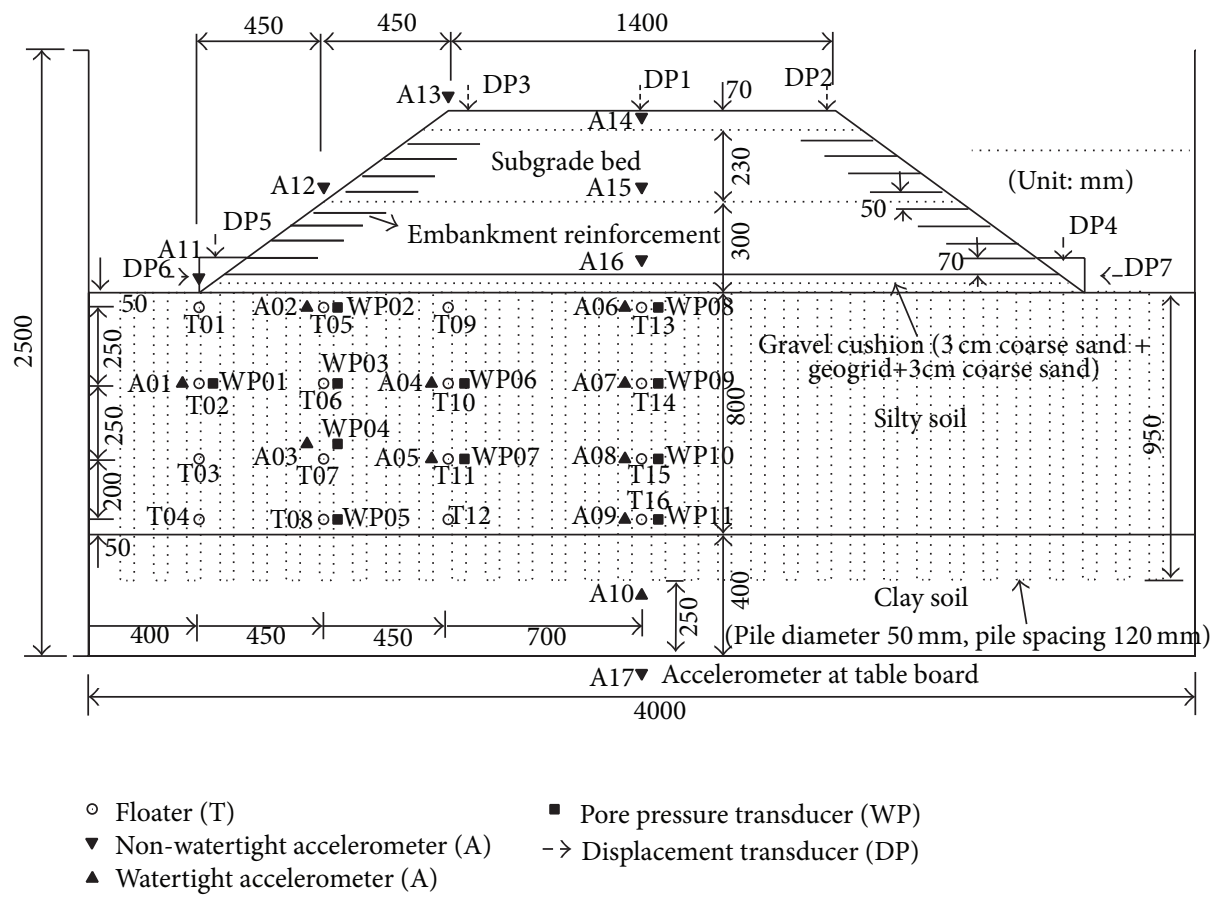

FIgURE 3: Model and arrangement of instruments (unit: $\mathrm{mm}$ ).

and both sides convex along the cross-sectional direction of subgrade.

(5) During excavation foundation, there is no obvious dislocation pile.

5.2. Distribution of Excess Pore Water Pressure. Figure 4 shows the relation between excess pore water pressure and loading acceleration. At $0.030 \mathrm{~g}, 0.097 \mathrm{~g}$, and $0.161 \mathrm{~g}$ loading acceleration, excess pore water pressure is less at different depth of soil between piles. While at $0.252 \mathrm{~g}$ loading acceleration, it rapidly increases and reaches its maximal value during the whole course of load, which illustrates that the soil between piles has been liquefied. The excess pore water pressure at $0.325 \mathrm{~g}$ loading acceleration is less than that $0.252 \mathrm{~g}$ loading acceleration, because soil between piles has been liquefied at the previous step loading $(0.252 \mathrm{~g})$, which causes the upper load borne by pile and soil to redistribute and makes the effective overlying stress of soil between piles decrease.

As shown in Figure 3, WP8 and WP11 are, respectively, located at the top and bottom of silty soil layer on the foundation center line, and WP9 is in the middle of silty soil layer, the excess pore pressure dissipation for WP8 is more easy. So compared with untreated foundation model test during the process of earthquake, especially at high loading acceleration, the excess pore water pressure of WP9 and WP11 of untreated foundation is higher than that of untreated foundation; however the change of excess pore water pressure for WP8 is small.

Compared with untreated foundation model test, excess pore water pressure of stone column composite foundation is less than that of untreated foundation model at the same

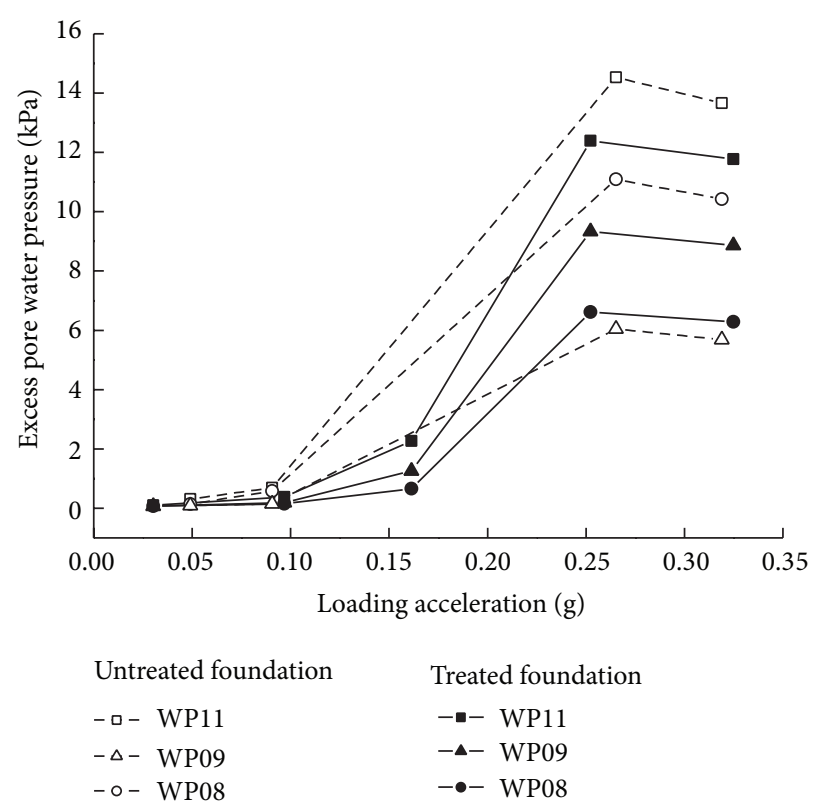

FIGURE 4: The relation between excess pore water pressure and loading acceleration.

loading acceleration. It shows that stone column composite foundation can effectively restrain the increase of excess pore water pressure to improve the antiliquefaction ability of ground.

5.3. Response Acceleration Amplification Coefficient of Subgrade. When loading acceleration is less than $0.161 \mathrm{~g}$, the foundation is not liquefied and response acceleration 


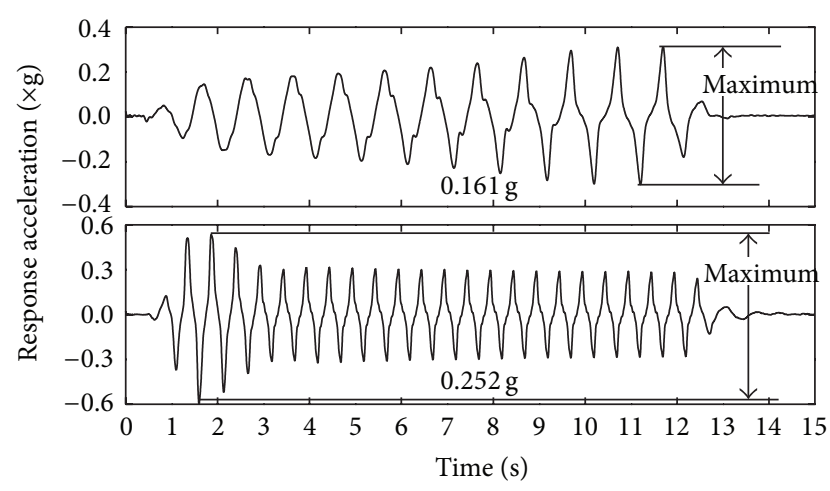

FIGURE 5: Values of response acceleration amplitude.

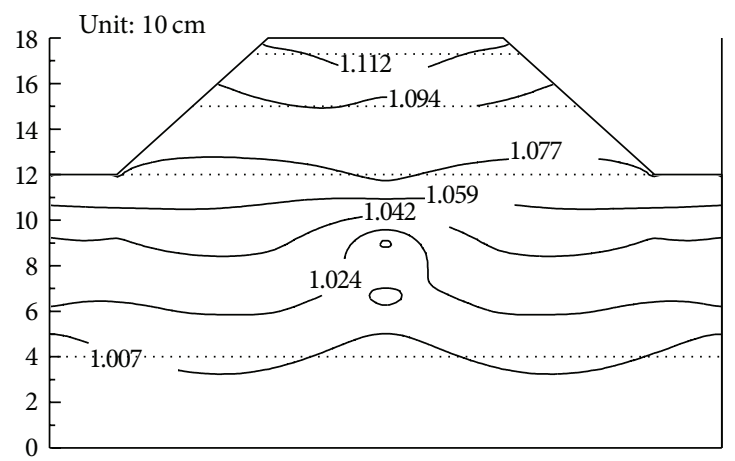

FIGURE 6: At $0.030 \mathrm{~g}$ loading acceleration.

amplitude is almost unchanged at each measuring point, so the average amplitude of response wave on the time-history curve is taken as response acceleration amplitude. While when loading acceleration is $0.252 \mathrm{~g}$ and $0.325 \mathrm{~g}$, the response acceleration amplitude gradually enlarges due to liquefaction of soil between piles, and relatively decreases with continuous load after reaching its maximum value, so the maximum amplitude of response wave on the time-history curve is taken as response acceleration amplitude. Although they are not the values of response acceleration at the same time, enough to reflect the largest destructive power at each point of subgrade during load. Figure 5 shows the value of response acceleration amplitude of accelerometer No. A16 at $0.161 \mathrm{~g}$ and $0.252 \mathrm{~g}$ loading acceleration.

Using acceleration record of each model measuring points under all input loads, the contour of response acceleration amplification coefficient relative to table board acceleration is drawn, as shown in Figures 6, 7, 8, 9, and 10.

(1) The response acceleration of subgrade increases with the increase of the distance away from the table board during the course of loading acceleration. At less than $0.161 \mathrm{~g}$ loading acceleration, the response acceleration of subgrade is close to the corresponding input acceleration of table board, and its amplification coefficient is about 1.0. It illustrates that the saturated silty soil layer has not yet been liquefied

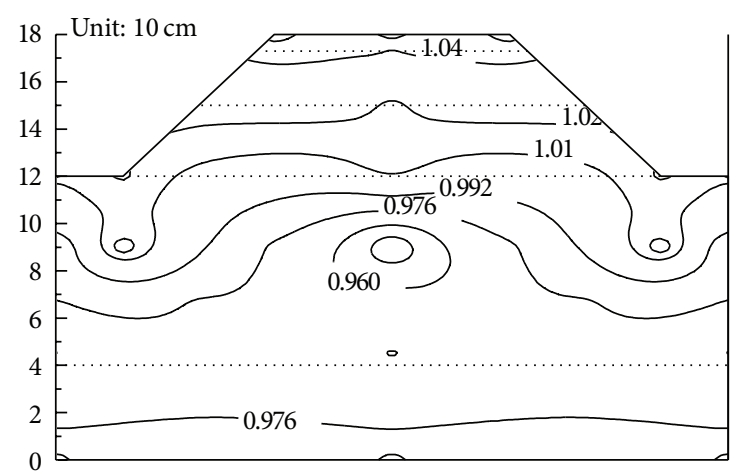

FIgURE 7: At $0.097 \mathrm{~g}$ loading acceleration.

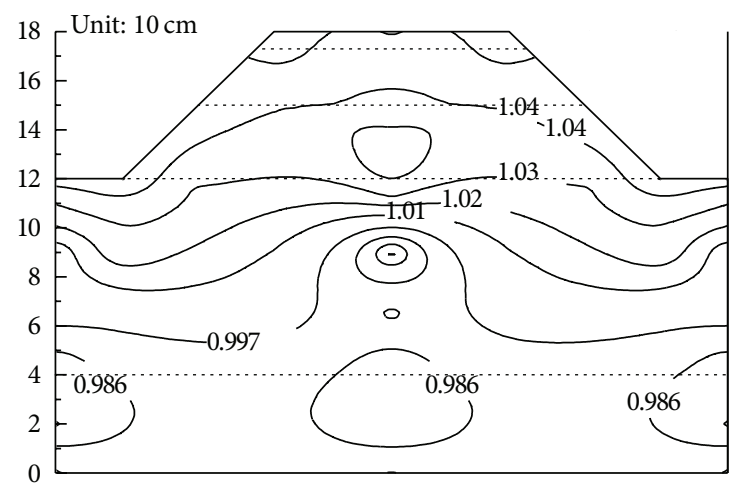

FIGURE 8: At $0.161 \mathrm{~g}$ loading acceleration.

and the integral rigidity of the foundation has almost no change.

(2) When loading acceleration increases to $0.252 \mathrm{~g}$, the response acceleration amplification coefficient increases obviously and reaches its peak, the change of which ranges from 1.259 to 3.0. The main reason is that the saturated silty soil between piles is liquefied, which leads to response acceleration amplification coefficient to increase rapidly.

(3) At $0.325 \mathrm{~g}$ loading acceleration, the response acceleration amplification coefficient reduces relatively and ranges from 1.121 to 1.849. Due to the stress of pile and soil distributed after soil between piles liquefaction, most stress is shared by piles, the integral rigidity of foundation decreases greatly, although the amplitude of response acceleration is still larger, the capacity of vibration transmission for the whole foundation is reduced, and result in the response acceleration amplification coefficient is less than that at the former loading acceleration.

(4) The response acceleration amplification coefficient of clay layer is close to 1.0 at less than $0.161 \mathrm{~g}$ loading acceleration, and it is slightly more than 1.0 at $0.252 \mathrm{~g}$ and $0.325 \mathrm{~g}$ loading accelerations. It illustrates that during the course of loading acceleration, amplification effect of response acceleration is obvious in silty soil, but not in clay layer. 


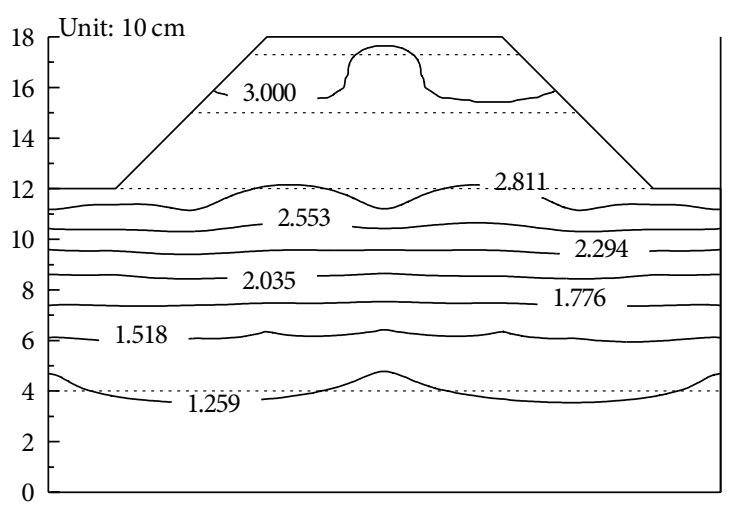

FIGURE 9: At $0.252 \mathrm{~g}$ loading acceleration.

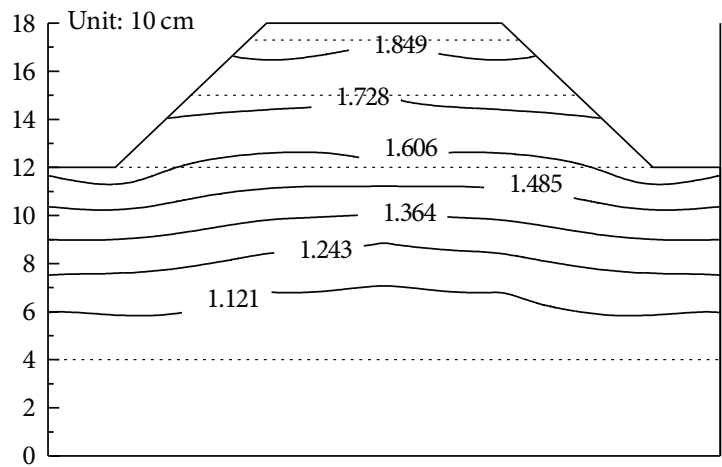

Figure 10: At $0.325 \mathrm{~g}$ loading acceleration.

5.4. Displacement of Subgrade. Figure 11 shows the vertical distribution law of shear displacement of foundation. There is almost no shear displacement in silty soil at less than $0.161 \mathrm{~g}$ loading acceleration, while shear displacement greatly increases at $0.252 \mathrm{~g}$ loading acceleration and further increases at $0.325 \mathrm{~g}$ loading acceleration. As a result of soil between piles liquefied and excess pore water pressure rising, the integral rigidity of foundation decreases greatly, which leads to shear displacement to increase. However, there is almost no shear displacement in clay soil during the course of load.

The shear displacement of different measuring points increases with the increase of input load and the distance away from the table board. Compared with untreated foundation, under the same load condition, the shear displacement of stone column composite foundation is less than that of untreated foundation. It illustrates that stone column composite foundation can effectively improve the resistance ability of shear deformation of foundation and enhance the whole earthquake resistance ability.

Figure 12 shows that the accumulated settlement of ground surface decreases gradually with the increase of the distance away from the ground center line. The foundation begins to uplift nearby the toe of embankment. Generally, within the range of ground surface covered with the embankment, the form of settlement is midst concave and both sides convex along subgrade transverse section direction.

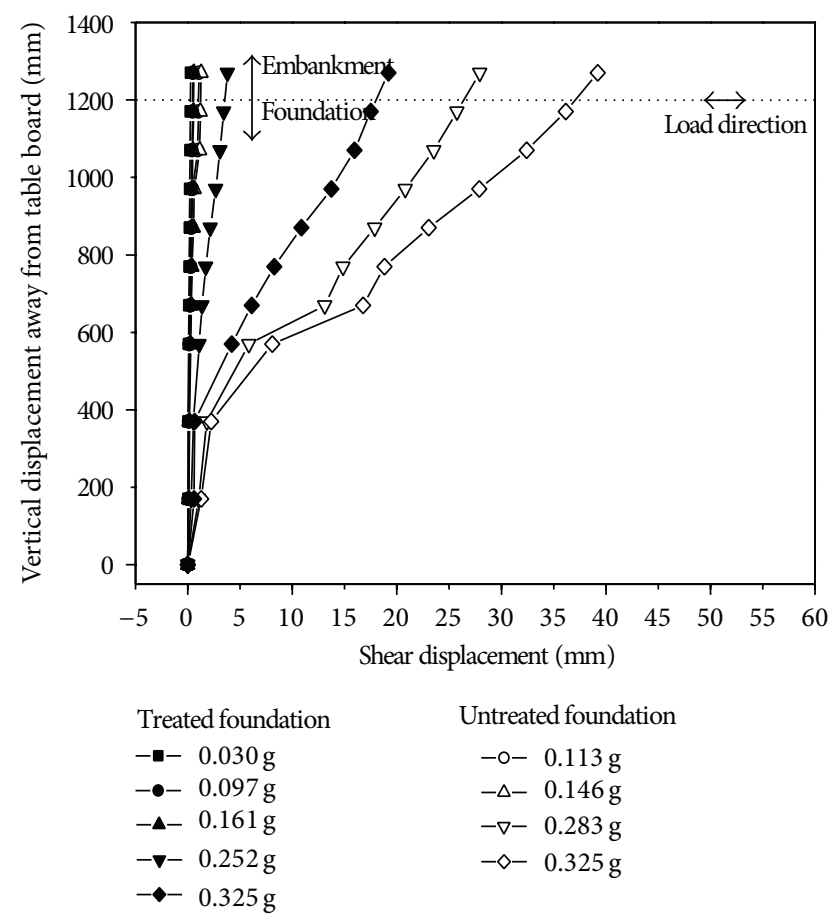

FIGURE 11: The vertical distribution of foundation shear displacement.

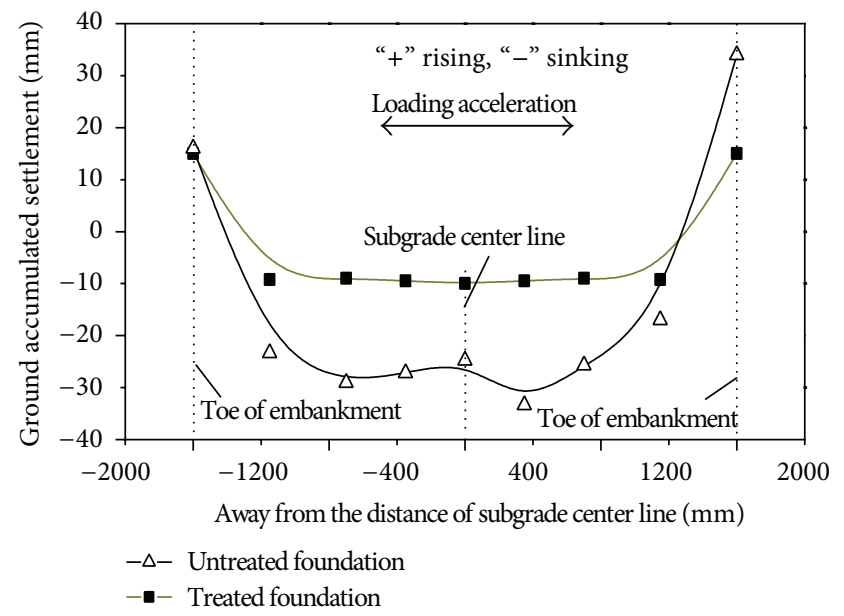

FIgURE 12: The accumulated settlement distribution of ground surface along subgrade transverse section direction.

Compared with untreated foundation model, the settlement of stone column model is very small, and the settlement of ground surface and subgrade surface is relatively uniform. The results indicate that the settlement of foundation and subgrade can be greatly reduced by stone column composite foundation.

\section{Conclusions}

(1) The response acceleration amplification coefficient of subgrade is about 1.0 at less than $0.161 \mathrm{~g}$ loading 
acceleration, while increases rapidly at 0.252 g loading acceleration as a result of silty soil between piles liquefied. Due to the integral rigidity of foundation great decreasing, the response acceleration amplification coefficient at $0.325 \mathrm{~g}$ loading acceleration is less than that at the former loading acceleration. The response acceleration of subgrade increases with the increasing of the distance away from the table board, and it is larger in silty soil, but not in clay layer.

(2) At less than $0.161 \mathrm{~g}$ loading acceleration, there is almost no shear displacement, while at $0.252 \mathrm{~g}$ and $0.325 \mathrm{~g}$ loading acceleration, the shear displacement significantly increases in silty soil. Under the same loading acceleration condition, the shear displacement of stone column composite foundation is less than that of untreated foundation. The accumulated settlement and nonuniform settlement of ground can be greatly reduced by stone column composite foundation.

(3) The test results show that the design meets seismic resistant requirements of Beijing-Shanghai high speed railway under the condition of 7-degree seismic fortifications.

\section{Conflict of Interests}

The authors declare that there is no conflict of interests regarding the publication of this paper.

\section{Acknowledgments}

This research is supported by the National Basic Research Program of China (no. 2013CB036405), the Key Research Program of the Chinese Academy of Sciences (no. KZZDEW-05), and the Natural Science Foundation of China (nos. 51209201 and 51279198). These financial supports are gratefully acknowledged.

\section{References}

[1] M. A. Dafalla, "Effects of clay and moisture content on direct shear tests for clay-sand mixtures," Advances in Materials Science and Engineering, vol. 2013, Article ID 562726, 8 pages, 2013.

[2] K. Ishihara, "Liquefaction and flow failure during earthquakes," Geotechnique, vol. 43, no. 3, pp. 351-415, 1993.

[3] W. D. L. Finn and N. Fujita, "Piles in liquefiable soils: seismic analysis and design issues," Soil Dynamics and Earthquake Engineering, vol. 22, no. 9-12, pp. 731-742, 2002.

[4] L. Fang and M. Xu, "Evaluation method for liquefaction discrimination of gravel columns composite ground," Journal of Earthquake Engineering and Engineering Vibration, vol. 26, no. 1, pp. 193-197, 2006.

[5] L. Zhang, M.-H. Zhao, and W. He, "Working mechanism of two-direction reinforced composite foundation," Journal of Central South University of Technology, vol. 14, no. 4, pp. 589-594, 2007 (Chinese).

[6] M.-H. Zhao, B.-H. Ma, and L. Zhang, "Analysis of time effect of pile-soil stress ratio in gravel-pile composite foundation,"
Journal of Central South University (Science and Technology), vol. 39, no. 4, pp. 831-837, 2008.

[7] C. F. Chen, Y. Yang, S. J. Xiao, and Z. J. Zhou, "Residual settlement calculation of geocell cushion over gravel piles," Journal of Central South University of Technology, vol. 15, pp. 21-27, 2008.

[8] K. D. Sujit and C. B. Mukul, "Improved performance of soft clay foundations using stone columns and geocell-sand mattress," Geotextiles and Geomembranes, vol. 41, pp. 26-35, 2013.

[9] K. Deb, N. K. Samadhiya, and J. B. Namdeo, "Laboratory model studies on unreinforced and geogrid-reinforced sand bed over stone column-improved soft clay," Geotextiles and Geomembranes, vol. 29, no. 2, pp. 190-196, 2011.

[10] K. Deb and A. Dhar, "Optimum design of stone columnimproved soft soil using multiobjective optimization technique," Computers and Geotechnics, vol. 38, no. 1, pp. 50-57, 2011.

[11] K. Adalier, A. Elgamal, J. Meneses, and J. I. Baez, "Stone columns as liquefaction countermeasure in non-plastic silty soils," Soil Dynamics and Earthquake Engineering, vol. 23, no. 7, pp. 571-584, 2003.

[12] Z. Zhang, J. Han, and G. B. Ye, "Numerical investigation on factors for deep-seated slope stability of stone columnsupported embankments over soft clay," Engineering Geology, vol. 168, pp. 104-113, 2014.

[13] S. R. Lo, R. Zhang, and J. Mak, "Geosynthetic-encased stone columns in soft clay: a numerical study," Geotextiles and Geomembranes, vol. 28, no. 3, pp. 292-302, 2010.

[14] R. S. Sharma, B. R. P. Kumar, and G. Nagendra, "Compressive load response of granular piles reinforced with geogrids," Canadian Geotechnical Journal, vol. 41, no. 1, pp. 187-192, 2004.

[15] C.-S. Wu and Y.-S. Hong, "The behavior of a laminated reinforced granular column," Geotextiles and Geomembranes, vol. 26, no. 4, pp. 302-316, 2008.

[16] C.-S. Wu and Y.-S. Hong, "Laboratory tests on geosyntheticencapsulated sand columns," Geotextiles and Geomembranes, vol. 27, no. 2, pp. 107-120, 2009.

[17] K. Deb, "Modeling of granular bed-stone column-improved soft soil," International Journal for Numerical and Analytical Methods in Geomechanics, vol. 32, no. 10, pp. 1267-1288, 2008.

[18] D. Qi, Z. R. Feng, and J. P. Chen, "Experimental study on vibration responses of composite foundation of gravel piles," Journal of Earthquake Engineering and Engineering Vibration, vol. 25, no. 5, pp. 132-136, 2005.

[19] G. L. Jiang, X. F. Liu, J. W. Zhang, and R. Y. Zhao, "Shaking table test of composite foundation reinforcement of saturated silty soil for high speed railway," Frontiers of Architecture and Civil Engineering in China, vol. 1, no. 3, pp. 353-360, 2007.

[20] X. Z. Ling, C. Wang, and C. Wang, "Scale modeling method of shaking table test of dynamic interaction of pile-soil-bridge structure in ground of soil liquefaction," Chinese Journal of Rock Mechanics and Engineering, vol. 23, no. 3, pp. 450-456, 2004. 

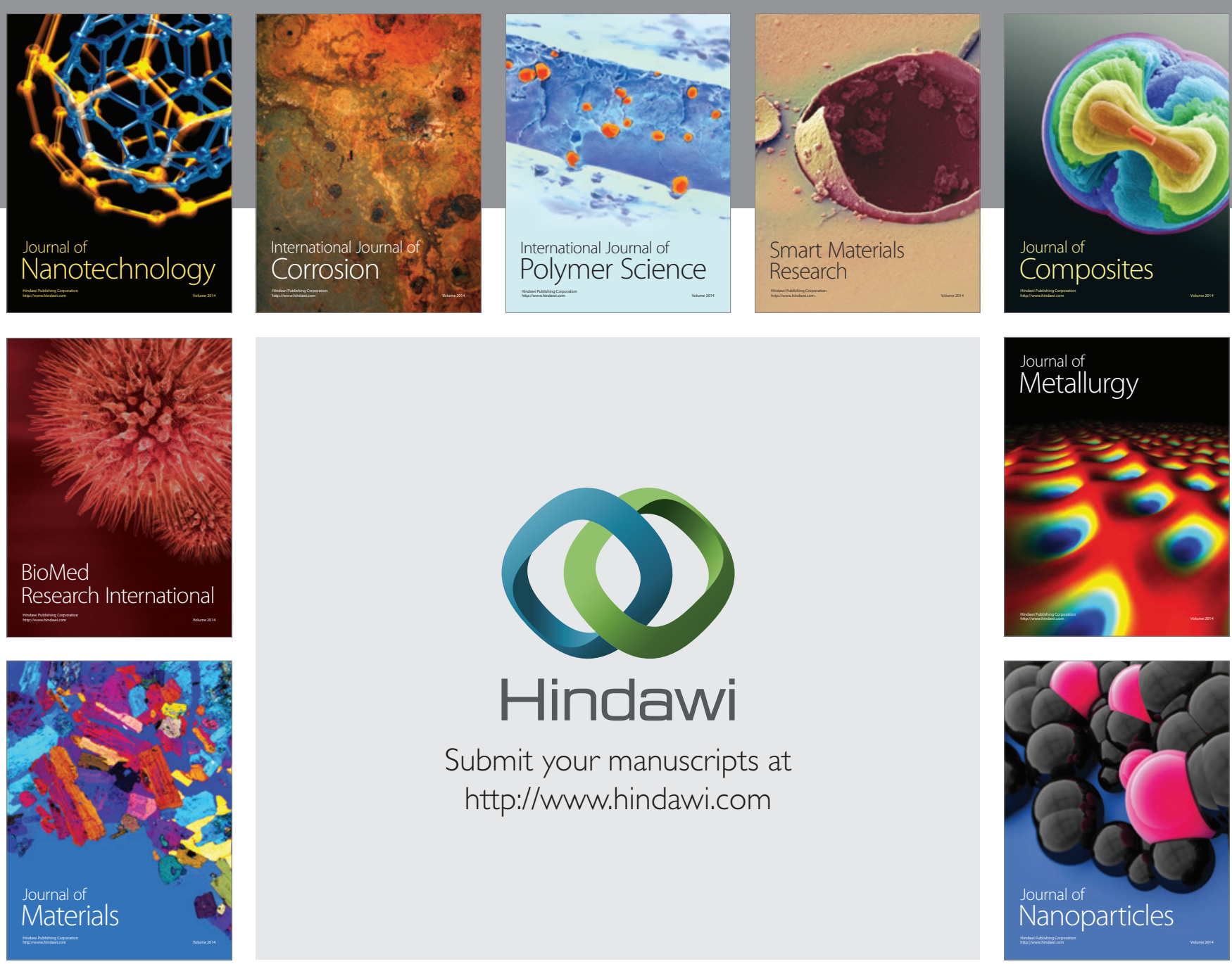

Submit your manuscripts at http://www.hindawi.com
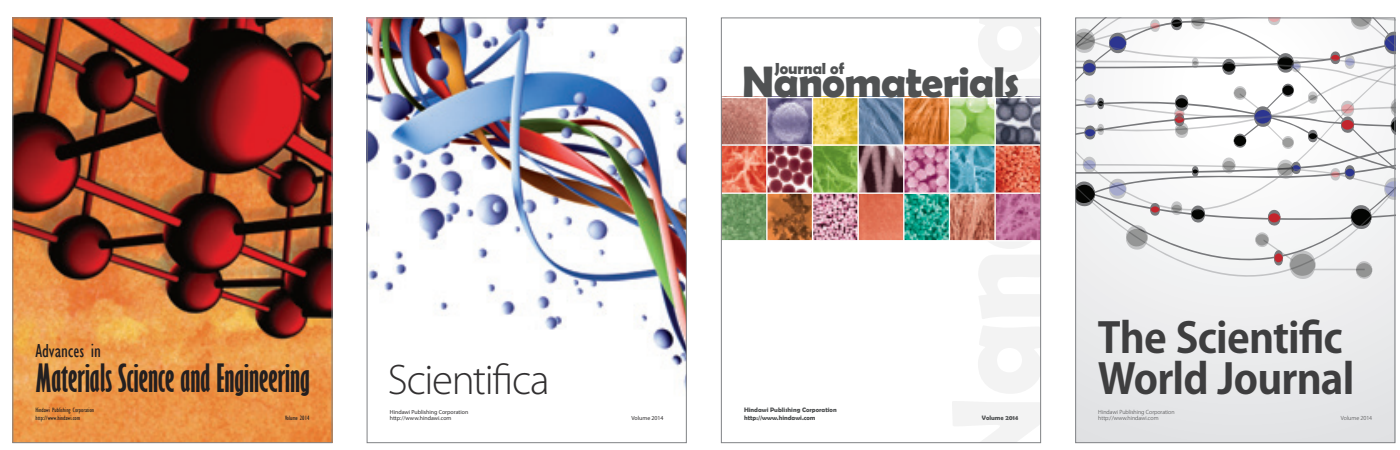

\section{The Scientific World Journal}
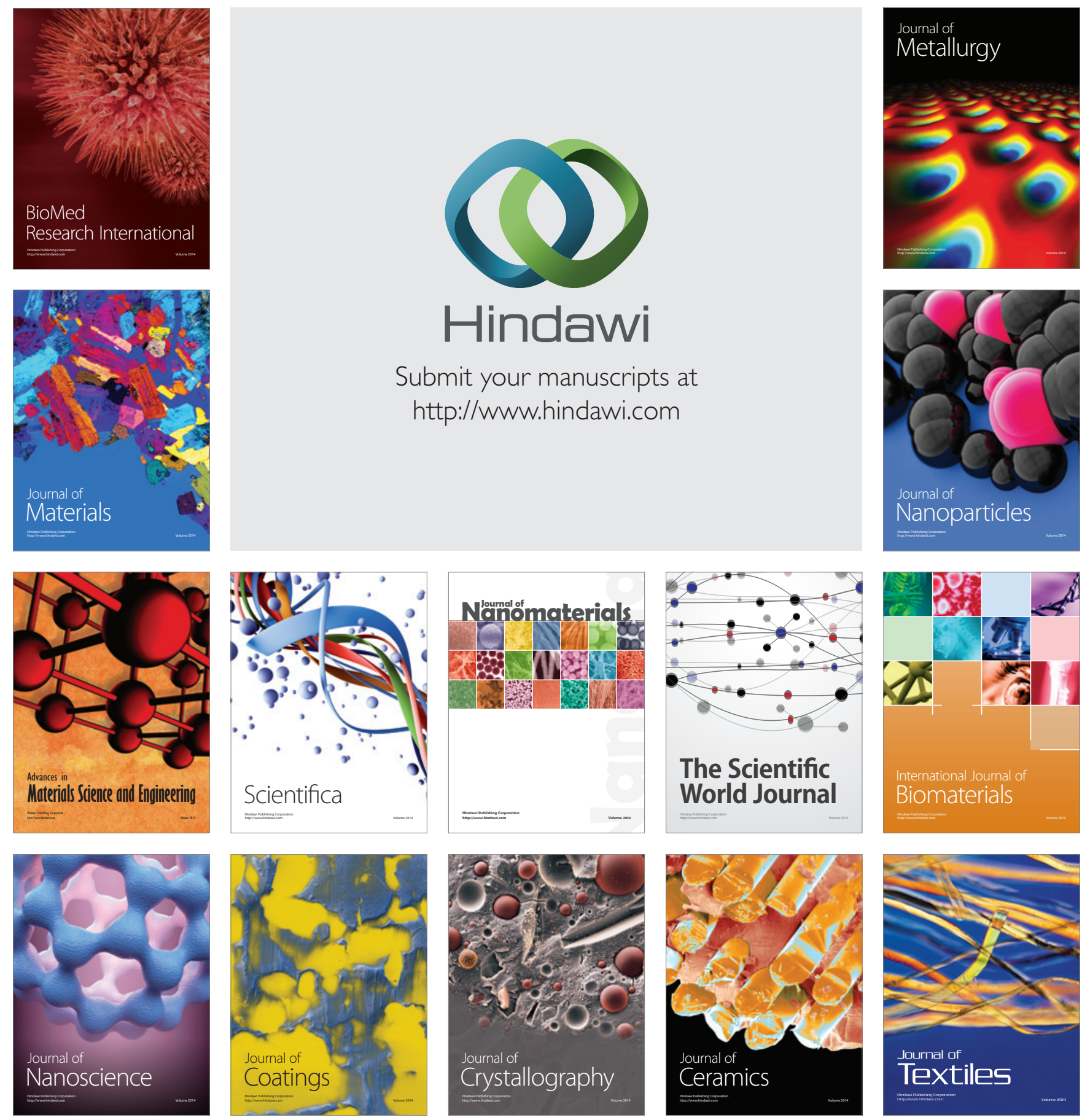